\title{
Nauczyciel kształcenia zintegrowanego a edukacja dla zrównoważonego rozwoju
}

\section{Wprowadzenie}

Od lat toczy się dyskusja nad modernizacją edukacji w Polsce. W jakim kierunku powinny podążać reformy? Co jest istotą unowocześniania szkoły? Jaka powinna być edukacja dziecka? Jaki powinien być nauczyciel współczesnej szkoły? Poszukujemy odpowiedzi na wiele pytań, ale jak pisał 20 lat temu Jacques Delors kierunek tych zmian wyznacza nam przyszłość „musimy myśleć o naszej przyszłości i wspólnie ją budować”. Podobnie uważał Jerome Bruner „Potrzebujemy reformy szkolnictwa przeprowadzonej z większą świadomością tego, dokąd zmierzamy oraz głębszym przekonaniem, jakimi ludźmi chcielibyśmy się stać"2.

Wydaje się, że koncepcja zrównoważonego rozwoju idealnie wpisuje się w wyzwania przyszłości. Co prawda, w naszym kraju ta idea jest najczęściej łączona z edukacją ekologiczną lub środowiskową, niekiedy wiąże się z wprowadzeniem poszerzonych treści do programów kształcenia podkreślających rozwój świadomości ekologicznej dzieci/

$1 \quad$ J. Delors, Edukacja: jest w niej ukryty skarb, Wydawnictwo UNESCO, Warszawa 1998, s. 14.

2 J. Bruner, Kultura edukacji, Wydawnictwo Universitas, Kraków 2006, s. 167. 
uczniów (Danuta Cichy ${ }^{3}$, Ligia Tuszyńska ${ }^{4}$, Anna Batorczak ${ }^{5}$, Alicja Walosik ${ }^{6}$, Ingrid Paśko ${ }^{7}$ ). Poczyniono też próby nieco innego podejścia, odważnej projekcji przyszłości i marzeń związanych z wychowaniem dzieci oraz rozbudzania naszego potencjału do przekształcania świata, uczenia odpowiedzialności i troski nie tylko o to, co teraźniejsze, ale nade wszystko, o to, co przyszłe ${ }^{8}$.

Potrzeba zmiany dotyczy nie tylko edukacji człowieka, ale wymusza też nowatorskie podejście do kształcenia przyszłych nauczycieli (nowe role, funkcje, zadania, kompetencje), przede wszystkim tych pracujących z dziećmi, najmłodszymi uczniami.

\section{Pojęcie i założenia koncepcji dla zrównoważonego rozwoju}

Początek kształtowania się idei zrównoważonego rozwoju sięga końca lat 60. XX wieku ${ }^{9}$, kiedy pojawiła się świadomość zagrożeń dla człowieka i jego środowiska życia. Idea zrównoważonego rozwoju była wiodącym tematem Konferencji Narodów Zjednoczonych w Sztokholmie w 1972 roku. Podczas konferencji, której hasłem było: „Mamy tylko jedną Ziemię" podjęto działania nad zdefiniowaniem rozwoju zrównoważonego, ekorozwoju w kontekście politycznym, ekologicznym, ekonomicznym oraz społecznym.

3 D. Cichy, Szkoła wobec wyzwań edukacji biologicznej i środowiskowej w XXI wieku, Instytut Badań Edukacyjnych, Warszawa 2001.

4 L. Tuszyńska, Diagnoza edukacji środowiskowej społeczności lokalnych w wybranych regionach Polski, Wydawnictwa Uniwersytetu Warszawskiego, Warszawa 2008.

5 A. Batorczak, Edukacja dla Zrównoważonego Rozwoju w Polsce i w Wielkiej Brytanii, rozprawa doktorska, napisana pod kierunkiem dr hab. A. Siemak-Tylikowskiej, prof. UW, https://depotuw.ceon.pl/bitstream/handle/item/457/Praca\%20doktorska.pdf?sequence=1 (dostęp: 5.07.2019).

$6 \quad$ A. Walosik, Przez edukację do zrównoważonego rozwoju, Wydawnictwo Uniwersytetu Pedagogicznego w Krakowie, Kraków 2013.

$7 \quad$ I. Paśko, Uczeń w młodszym wieku szkolnym jako uczestnik edukacji dla zrównoważonego rozwoju, „Pedagogika Przedszkolna i Wczesnoszkolna. Czasopismo Instytutu Pedagogiki Przedszkolnej i Szkolnej Uniwersytetu Pedagogicznego im. Komisji Edukacji Narodowej w Krakowie" 2018, nr 2/2(12/2), s. 289 - 302.

8 J. Bałachowicz, A. Korwin-Szymanowska, E. Lewandowska, A. Witkowska-Tomaszewska, Zrozumieć uczenie się. Zmienić wczesną edukację, Wydawnictwo Akademii Pedagogiki Specjalnej, Warszawa 2017.

926 maja 1969 roku Sekretarz Generalny ONZ Maha Thray Sithu U Thant przedstawił raport zatytułowany Problemy ludzkiego środowiska (The problems of human environment) - rezolucja nr 2398. 
Jednak po raz pierwszy pojęcie zrównoważony rozwój (sustainable development) zdefiniowano i opublikowano w raporcie Światowej Komisji Środowiska i Rozwoju ONZ zatytułowanym Nasza Wspólna Przyszłość (Our Common Future) w 1987 roku i w Agendzie 21 ${ }^{10}$. W powyższych dokumentach ${ }^{11}$, obok gospodarki i spraw socjalnych, wyznaczono środowisku jedną z podstawowych funkcji dalszego rozwoju cywilizacyjnego świata. W raporcie Gro Harlem Brundtland ${ }^{12}$ możemy dostrzec pełniejszy, humanistyczny wymiar koncepcji. Debaty i dyskusje nad możliwością praktycznych rozwiązań podejmowano także na kolejnych konferencjach ONZ i innych gremiach międzynarodowych.

Nie ulega wątpliwości, że zrównoważony rozwój jest pojęciem wieloznacznym, trudnym do zdefiniowania, co pozwala na wielorakie interpretacje. Niejednoznaczność i ogólnikowość spowodowała mnogość definicji i poszerzyła pole problemowe tego pojęcia. Początkowo związane było z zagrożeniami ekspansywnej gospodarki przemysłowej (m.in. ostrzeżenia, debaty, diagnoza przyczyn zagrożeń), następnie z wprowadzaniem pierwszych reform dotyczących zarządzania zasobami naturalnymi, a od przełomu XX i XXI wieku z wprowadzaniem transformacji społecznych, kulturowych, gospodarczych $\mathrm{w}$ różnych dziedzinach życia, w tym także w edukacji.

Pojęcie zrównoważony rozwój jest używane w dokumentach międzynarodowych, aktach prawnych i literaturze naukowej, ma ono charakter syntetyczny, holistyczny. Rozwój zrównoważony jest rozwojem gospodarczym, odnosi się do zagadnień ekonomicznych, jest zrównoważony, ponieważ zakłada harmonijne wykorzystanie zasobów przyrodniczych wraz z ich zachowaniem dla przyszłych pokoleń i zasobów ludzkich we wszystkich wymiarach, od biologicznych po kulturowe,

10 Agenda 21 to wszechstronny plan działania na wiek XXI dla Narodów Zjednoczonych, rządów i grup społecznych w każdym obszarze, w którym człowiek ma wpływ na środowisko. W Szczycie Ziemi uczestniczyli przedstawiciele 172 rządów, 2400 organizacji pozarządowych oraz 10000 dziennikarzy, zaś Agendę sygnowały 172 kraje, w tym Polska.

11 L. Tuszyńska, Nauki o środowisku przyrodniczym, [w:] A. Korwin-Szymanowska, E. Lewandowska, L. Tuszyńska, Edukacja środowiskowa w kształceniu nauczycieli w perspektywie praktycznej, Wydawnictwo Akademii Pedagogiki Specjalnej, Warszawa 2015.

12 Działalność Komisji Brundtland przyczyniła się także do zwołania Szczytu Ziemi w 1992 roku w Rio de Janeiro. 
zakłada wprowadzenie ładu w przestrzeni, ma też być rozwojem trwałym, nieprzerwanym ${ }^{13}$.

Zdaniem Artura Pawłowskiego ${ }^{14}$ „zrównoważony rozwój to taki, który gwarantuje zaspokojenie potrzeb obecnych pokoleń, nie zagrażając zdolności przyszłych pokoleń do zaspokojenia ich własnych potrzeb"15.

Jak słusznie zauważa Józefa Bałachowicz

Zrównoważony rozwój dotyczy przede wszystkim relacji między ludźmi, pokoleniami żyjącymi współcześnie i w przyszłości oraz relacji między człowiekiem a jego środowiskiem życia. Ta wykładnia ma w pełni wymiar moralny i pedagogiczny, bowiem dotyka kanwy myślenia i działania pedagogicznego, jaką jest służba integracji międzypokoleniowej i wewnątrzpokoleniowej, dbałość o środowisko życia i pomyślny rozwój człowieka ${ }^{16}$.

Badacze środowiska przyrodniczego, humaniści zajmujący się filozofią człowieka są zdania, że koncepcja zrównoważonego rozwoju ,jest pierwszą w historii życia ziemi świadomie określaną próbą uniknięcia samozagłady, a jednocześnie próbą określenia kierunków działań człowieka w kontekście jego relacji z przyrodą" ${ }^{17}$.

Koncepcja dla zrównoważonego rozwoju zakłada planowanie działań zapewniających poprawę jakości środowiska przyrodniczego oraz życia ludzi we wszystkich obszarach ich funkcjonowania, zarówno obecnie, jak i w przyszłości ${ }^{18}$.

13 F. Plit, Edukacja dla zrównoważonego rozwoju, [w:] E. Rydz, A. Kowalak (red.), Świadomość ekologiczna a rozwój regionalny w Europie Środkowo-Wschodniej, Wydawnictwo Naukowe Akademii Pomorskiej, Słupsk 2008, s. 13-20.

14 A. Pawłowski, Teoretyczne uwarunkowania rozwoju zrównoważonego, http://towarzystwo.ros.edu.pl/images/roczniki/archive/pp_2009_071.pdf (dostęp: 30.08.2019).

15 Zbliżoną definicję wygłoszono na II Konferencji Ekologicznej w Warszawie w 2006 roku. Zrównoważony rozwój to „Proces mający na celu zaspokojenie aspiracji rozwojowych obecnego pokolenia, w sposób umożliwiający realizację tych samych dążeń następnym pokoleniom".

16 J. Bałachowicz, Idea zrównoważonego rozwoju w edukacji dziecka, „Prima Educatione" 2017, nr 1 (rocznik wydawany online).

17 M. Degórski, Postrzeganie rozwiązań zrównoważonego rozwoju w kontekście rosnącej świadomości ekologicznej ludności na przykładzie wybranych gmin i miast obszaru metropolitalnego Warszawy, [w:] E. Rydz, A. Kowalak (red.), Świadomość ekologiczna..., s. 31.

18 B. Dobrzańska, G. Dobrzański, D. Kiełczewski, Ochrona środowiska przyrodniczego, PWN, Warszawa 2010. 
Idea zrównoważonego rozwoju szybko zyskała popularność na Zachodzie, jednak w naszym kraju wdrażanie i rozumienie jej jest powolne.

\section{Edukacja (wczesnoszkolna) dla zrównoważonego rozwoju}

Od momentu formułowania się idei zrównoważonego rozwoju zwracano uwagę na szczególną rolę edukacji jako ważnego czynnika przemian mentalnych ludzi, czynnik budujący ludzki potencjał do przeciwdziałania kryzysom i podjęcia działań w celu zwiększenia ludzkiej odpowiedzialności za przyszłość. W XX wieku do Polski przenikały nowe idee, myśli i wyzwania edukacyjne między innymi za sprawą Raportów Klubu Rzymskiego, ONZ i UNESCO ${ }^{19}$.

W praktyce edukacja dla zrównoważonego rozwoju jest pojęciem szerszym niż edukacja ekologiczna (przyrodnicza czy środowiskowa). Obejmuje swym zasięgiem m.in.: prawa człowieka, rozwiązywanie konfliktów, dobre rządy, gospodarkę, zdrowie, kulturę i sztukę, turystykę, oznacza także multidyscyplinarne podejście do reformy systemu edukacji, oferujące wszystkim ludziom, we wszystkich kontekstach edukacyjnych i we wszystkich okresach życia człowieka okazję do nauki takiego stylu życia, który umożliwi im trwały rozwój. Edukacja dla zrównoważonego rozwoju wykracza swym zasięgiem poza formalne systemy edukacyjne, chociaż powinna wywierać na nie wpływ i mieć swoje odzwierciedlenie w podstawach programowych/programach, podręcznikach, formach i metodach uczenia się (nauczania, wychowania). Pojęcie edukacji dla zrównoważonego rozwoju ma szereg określeń:

- edukacja, która umożliwia uczącemu się zdobywanie umiejętności, wiedzy i przymiotów zapewniających mu trwały rozwój,

- edukacja jednakowo dostępną na wszystkich szczeblach i we wszelkich społecznych kontekstach (rodzinnym, szkolnym, zawodowym, w lokalnej społeczności),

- edukacja budująca odpowiedzialność obywatelska,

19 Mowa o raportach Donella H. Meadows, Dennis L. Meadows, Jørgen Randers i William W. Behrens III, Granice wzrostu z 1972 roku; Edgar Faure, Uczyć się, aby być z 1975 roku; James W. Botkin, Mahdi Elmandjra, Mircea Malitza, Uczyć się - bez granic. Jak zewrzeć „lukę ludzką? z 1982 roku; Jacques Delors, Edukacja. Jest w niej ukryty skarb z 1998 roku. 
- edukacja promująca demokrację poprzez uświadomienie jednostce jej praw i obowiązków,

- edukacja oparta na zasadzie nauki przez całe życie,

- edukacja wspierająca równomierny rozwój jednostki (schemat 1).

\section{Schemat 1. Określenia edukacji dla zrównoważonego rozwoju}

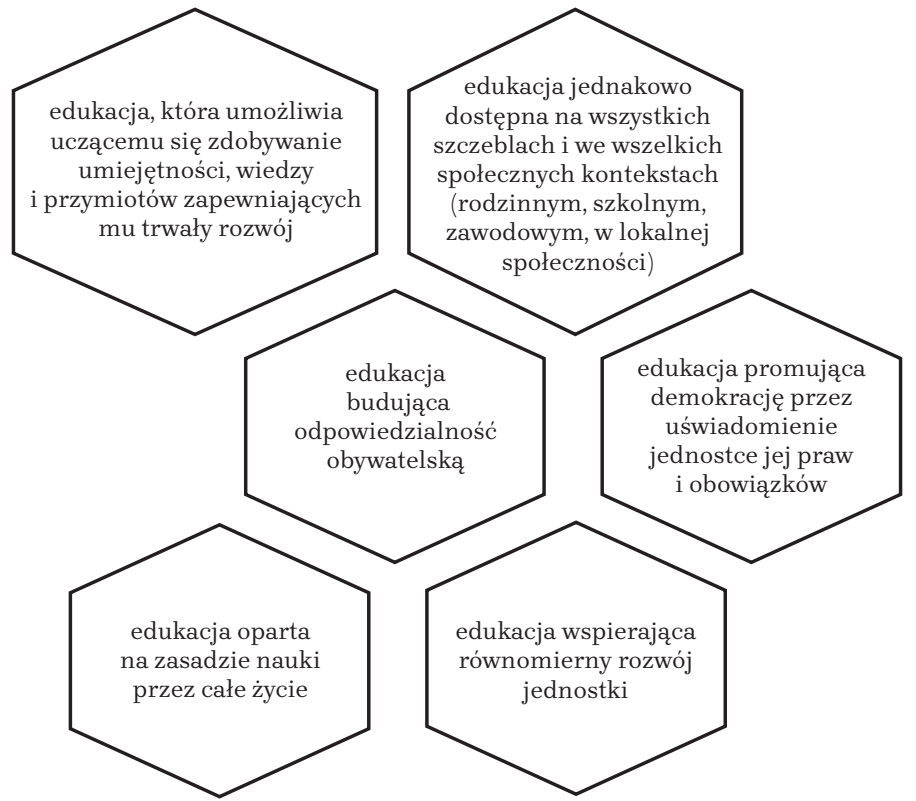

Źródło: opracowanie własne na podstawie: UNESCO a Dekada Edukacji dla Zrównoważonego Rozwoju, [w:] http://www.unesco.pl/edukacja/dekada-edukacji-nt-zrownowazonego-rozwoju/unesco-a-zrownowazony-rozwoj/ (dostęp: 30.08.2019).

Warto zapoznać się z poszerzonymi założeniami edukacji w koncepcji zrównoważonego rozwoju zawartej w raporcie dla UNESCO Międzynarodowej Komisji do Spraw Edukacji dla XXI wieku pod przewodnictwem Jacquesa Delors'a. W wyniku analizy nowych kategorii pojawiających się w raportach międzynarodowych ${ }^{20}$ dotyczących ucze-

20 Godne uwagi są także liczne raporty o stanie edukacji na świecie (Global Monitoring Reports): 2002 „Czy świat jest na właściwej drodze”; 2003/2004 „Równość w dostępie do edukacji”; (Gender and Education for All: The Leap to Equality); 2005 
nia się - naczelnej kompetencji współczesnego człowieka możemy zauważyć 6 paradygmatów edukacji, które zamieszczono w tabeli 1.

Tabela 1. Współczesne paradygmaty edukacji

\begin{tabular}{|l|l|}
\hline \multicolumn{2}{|c|}{ Paradygmaty edukacji XXI wieku } \\
\hline $\begin{array}{l}\text { Uczyć się, aby } \\
\text { wiedzieć }\end{array}$ & $\begin{array}{l}\text { Zdobywać narzędzia rozumienia siebie i świata, } \\
\text { poszukiwania wiedzy i mądrości, uczyć się instrumentów } \\
\text { uczenia się, aby uczyć się przez całe życie; }\end{array}$ \\
\hline $\begin{array}{l}\text { Uczyć się, aby } \\
\text { działać }\end{array}$ & $\begin{array}{l}\text { Stosować wiedzę w codziennym życiu, móc oddziaływać } \\
\text { na swoje środowisko, działać w nim twórczo } \\
\text { i odpowiedzialnie }\end{array}$ \\
\hline $\begin{array}{l}\text { Uczyć się, aby } \\
\text { zyć wspólnie }\end{array}$ & $\begin{array}{l}\text { Wykorzystywać wiedzę, wartości i umiejętności do } \\
\text { rozumienia innych, uczyć się w kooperacji, uczestniczyć } \\
\text { i współpracować z innymi na wszystkich płaszczyznach } \\
\text { działalności ludzkiej, budować obywatelstwo w świecie } \\
\text { pełnym współzależności }\end{array}$ \\
\hline $\begin{array}{l}\text { Uczyć się, } \\
\text { aby byćc }\end{array}$ & $\begin{array}{l}\text { Wykorzystywać wiedzę, wartości i umiejętności do } \\
\text { osobistego rozwoju, dążyć do poszukiwania wartości } \\
\text { i doskonalenia siebie, rozwoju wymiarów estetycznych } \\
\text { swego życia, zanurzenia się w kulturze, uczenie się dla } \\
\text { samej/samego siebie }\end{array}$ \\
\hline $\begin{array}{l}\text { Uczyć się, } \\
\text { aby być } \\
\text { innowacyjnym }\end{array}$ & $\begin{array}{l}\text { Rozumieć złożoności, paradoksy i konflikty, uczyć się } \\
\text { dostrzegania alternatywnych układów odniesienia, } \\
\text { nowych możliwości i projektów rozwiązań, } \\
\text { aby przekształcać siebie, społeczności lokalne } \\
\text { i społeczeństwo globalne }\end{array}$ \\
\hline $\begin{array}{l}\text { Uczyć się, aby } \\
\text { zyyć w sposób } \\
\text { zrównoważony }\end{array}$ & $\begin{array}{l}\text { Rozwijać refleksyjne podejście do życia, uczyć się } \\
\text { w kontekście stosowania norm, wyboru wartości, } \\
\text { równoważyć sprzeczności, aby kształtować swoje } \\
\text { środowisko życia i relacje z nim, swój styl życia w sposób } \\
\text { zrównoważony }\end{array}$ \\
\hline
\end{tabular}

Źródło: J. Bałachowicz, Idea zrównoważonego rozwoju..., s. 29.

„Jakość nauczania i dostęp do edukacji w różnych częściach świata” (Education for All: The Quality Imperative); 2006 „Alfabetyzacja”; (Literacy for Life); 2007 „Solidne podstawy” (Strong foundations); 2008 „Education for All by 2015. Will we make it?”; 2009 „Overcoming inequality: why governance matters?”; 2010 „Reaching the marginalized”; 2011 „The hidden crisis: Armed conflict and education”; 2012 „Youth and skills: Putting education to work”; 2013/2014 „Learning and teaching for development”; 2016 „Edukacja dla ludzi i planety”. 
Józefa Bałachowicz cele edukacji dla zrównoważonego rozwoju wyraziła w postaci wartości: wiedzieć (otwartość i dociekliwość poznawcza, potrzeba uczenia się, umiejętność wyrażania swoich myśli, refleksyjność i krytyczny ogląd świata), działać (odwaga w podejmowaniu zadań, poczucie skuteczności własnego działania, kreatywność, odpowiedzialność za efekty działań), żyć wspólnie (szacunek i troska o innych, dialogowość, tolerancja, współpraca i partycypacja, budowanie więzi), być (autonomia, zaufanie wobec świata, wolność, ugodowość, odpowiedzialność), być innowacyjnym (dostrzeganie perspektyw, możliwości, przewidywanie skutków, umiejętność podejmowania decyzji) i żyć w sposób zrównoważony (refleksyjne podejście do życia, autonomia i integracja, kształtowanie środowiska życia i stylu życia zgodnie z wartościami, w sposób zrównoważony $)^{21}$. Najważniejszym zadaniem edukacji jest umożliwienie ludzkości kierowania własnym rozwojem.

Istotną transformację systemu edukacji zainicjował kolejny Szczyt Ziemi w 2002 roku w Johannesburgu. Zgromadzenie ONZ i UNESCO ustanowiło lata 2005-2014 Dekadą Edukacji dla Zrównoważonego Rozwoju (DEdZR). Zadaniem tzw. Dekady Zmiany było „propagowanie zrównoważonych zachowań, inspirowanie krytycznego i twórczego myślenia, pozwalającego znaleźć rozwiązanie problemów umożliwiających trwały rozwój”22.

Głównym celem DEdZR było:

Wspieranie przez edukację dążeń promujących rozwój zrównoważony przyrodniczy, ekonomiczny, społeczny i kulturowy (...) przez:

- włączenie idei zrównoważonego rozwoju do systemu edukacji na wszystkich poziomach kształcenia,

- promowanie edukacji jako czynnika budowania trwałych więzi społecznych,

- umacnianie międzynarodowej współpracy w zakresie tworzenia innowacyjnych strategii i programów edukacyjnych w celu wdrażania zrównoważonego rozwoju,

- stałe dążenie do podnoszenia jakości kształcenia i zmiany postaw społecznych ${ }^{23}$.

21 J. Bałachowicz, Idea zrównoważonego rozwoju..., s. 31.

22 Polska Komisja ds. UNESCO, UNESCO a Dekada Edukacji dla Zrównoważonego Rozwoju, 2006, http://www.unesco.pl/edukacja/dekada-edukacji-nt-zrownowazonego-rozwoju/unesco-a-zrownowazony-rozwoj/ (dostęp: 30.08.2019).

23 D. Cichy, Dekada edukacji ekologicznej wzmocnieniem świadomości i działań społeczeństwa na rzecz środowiska, [w:] E. Rydz, A. Kowalak (red.), Świadomość ekologiczna..., s. 121. 
W 2005 roku w Wilnie Europejska Komisja ONZ przyjęła Strategię Edukacji dla Zrównoważonego Rozwoju, w której zawarto praktyczne wytyczne i wskazówki. Uznano, że edukacja dla zrównoważonego rozwoju może pomóc w urzeczywistnieniu się naszej wizji przyszłości. „Edukacja, będąca jednym z podstawowych praw człowieka, jest warunkiem wstępnym osiągnięcia zrównoważonego rozwoju oraz istotnym narzędziem właściwego zarządzania oraz promowania demokracji”"24. Celem powyższej Strategii było zachęcanie państw europejskich do opracowania oraz realizacji zasad zrównoważonego rozwoju w formalnych i nieformalnych systemach edukacji, do wyposażania ludzi w wiedzę, i umiejętności odnoszące się do zrównoważonego rozwoju. Ponadto zalecenia wskazywały na potrzebę zmiany systemu kształcenia, prowadzenia badań dotyczących modyfikacji metod nauczania. Dostrzeżono potrzebę wdrażania problematyki związanej z rozwojem zrównoważonym do programów edukacyjnych na wszystkich etapach kształcenia włącznie z edukacją przedszkolną. Priorytetem była także realizacja programów: „Edukacja dla Wszystkich” (Education for All) i „Dekada alfabetyzacji Narodów Zjednoczonych” (United Nations Litaracy Decade), „Po pierwsze edukacja” (Education First).

Nie ulega wątpliwości, że edukacja po raz pierwszy znalazła się na liście globalnych priorytetów ONZ, uznano ją za istotną siłę zdolną pokierować światem wobec tak licznych wyzwań.

\section{Nauczyciel kształcenia zintegrowanego w kontekście edukacji dla zrównoważonego rozwoju}

Zmieniająca się rzeczywistość zrodziła potrzebę nowego typu nauczyciela. Współczesne podejście do procesu kształcenia zakłada przygotowanie młodego pokolenia do samodzielnego uczenia się przez całe życie, dążenie do samorozwoju, samodoskonalenia się, wyposażenie w stosowne narzędzia do realizacji tego celu, rozwijanie zainteresowań oraz stwarzanie warunków niezbędnych do samodzielnego zdobywania wiedzy i umiejętności.

Obecnie od nauczyciela oczekuje się, że umożliwi uczniom rozumienie i orientację we współczesnym świecie, wyzwoli twórcze

24 Strategia Edukacji dla Zrównoważonego Rozwoju, Europejska Komisja Gospodarcza ONZ, Ministerstwo Środowiska, Warszawa 2008, s. 3. 
działanie i myślenie. Nauczyciel powinien być osobą o niepowtarzalnej indywidualności, refleksyjną, kreatywną, myślącą krytycznie, umiejącą współpracować z innymi, podejmującą nowe wyzwania i otwierającą się na zmiany społeczne oraz edukacyjne. To osoba dążąca do poszukiwania lub tworzenia wiedzy, pełna empatii, gotowa do dialogu, dostrzegająca potrzeby ludzi. Współczesny nauczyciel ma inspirować i motywować, rozwijać zainteresowania poznawcze uczniów, stwarzać warunki i wspierać w realizacji celów współczesnej edukacji. Mimo że dominacja nauczyciela została zastąpiona współuczestnictwem, to nadal jest on organizatorem i kierownikiem procesu dydaktyczno-wychowawczego.

Nauczyciel realizuje szereg zadań ${ }^{25}$ i pełni różne funkcje: kształcącą, wychowawczą, opiekuńczą, środowiskową, orientacyjno-życiowego ukierunkowania dzieci, socjalizacyjną i badawczą ${ }^{26}$. Ponadto, jak zauważa Kazimierz Żegnałek ${ }^{27}$ funkcję kierowniczą (liderską), integracyjną, organizacyjną, koordynującą, diagnostyczną i opiekuńczą, inspiracyjną, a także innowacyjną.

W ostatnim okresie obok zadań i funkcji często pojawia się termin kompetencja. Jan Průcha ${ }^{28}$ kompetencje nauczycielskie definiuje jako zbiór profesjonalnych umiejętności, wiedzy, wartości oraz postaw, którymi musi dysponować każdy nauczyciel, aby mógł efektywnie wykonywać swoją pracę. Na temat kompetencji nauczycielskich wypowiadało się wielu pedagogów, wśród nich m.in.: Chris Kyriacou, Stanisław Dylak, Barbara Żechowska, Bogusława D. Gołębniak, Jolanta Szempruch, Robert Kwaśnica, Małgorzata Żytko, Wacław Strykowski.

Najważniejsze kompetencje, bez których nie można kształtować pozostałych, nazwano kompetencjami kluczowymi. W Polsce przyjęto pięć kompetencji kluczowych nauczycieli:

1) planowanie, organizowanie i ocenianie własnego uczenia się,

2) skuteczne porozumiewanie się w różnych sytuacjach,

25 Zob. Cz. Kupisiewicz, Dydaktyka ogólna, Wydawnictwo Graf Punkt, Warszawa 2000, s. 214-215.

26 Cz. Banach, Nauczyciel, [w:] W. Pomykało (red.), Encyklopedia pedagogiczna, Wydawnictwo Fundacja Innowacja, Warszawa 1993, s. 436.

27 K. Żegnałek, Dydaktyka ogólna. Wybrane zagadnienia, Wyższa Szkoła Pedagogiczna im. Janusza Korczaka, Warszawa 2005, s. 332 - 333.

28 J. Průcha, Pedeutologia, [w:] B. Śliwerski (red.), Pedagogika. Pedagogika wobec edukacji, polityki oświatowej i badań naukowych, t. 2, GWP, Gdańsk 2006, s. 292-316. 
3) efektywne współdziałanie w zespole,

4) rozwiązywanie problemów w twórczy sposób,

5) sprawne posługiwanie się komputerem ${ }^{29}$.

$\mathrm{Na}$ kompetencje nauczycieli wczesnej edukacji zwróciła uwagę Hanna Hamer ${ }^{30}$. Uważa ona, że najistotniejsze są trzy rodzaje kompetencji: 1) kompetencje specjalistyczne, które obejmują wiedzę i umiejętności dotyczące nauczania na tym poziomie, gdzie działalność edukacyjna odnosi się do: edukacji polonistycznej, matematycznej, środowiskowej, plastycznej, muzycznej, technicznej, ruchowej ${ }^{31} ; 2$ ) kompetencje dydaktyczne, które dotyczą umiejętności projektowania zintegrowanych jednostek tematycznych, uwzględniania specyfiki rozwojowej dzieci w młodszym wieku szkolnym, opanowanie sztuki motywowania uczniów do nauki, umiejętność diagnozowania dziecka i jego rozwoju; 3) kompetencje psychologiczne, np. umiejętność porozumiewania się ze wszystkimi podmiotami edukacyjnymi, budowania zgranego zespołu uczniowskiego i kierowania nim, umiejętność kontrolowania emocji.

Podstawowe znaczenie edukacji dla podejmowania działań na rzecz zrównoważonego rozwoju wynika ze zmian w myśleniu o roli edukacji, a przede wszystkim roli nauczyciela.

Kompetencje nauczycieli edukacji na rzecz zrównoważonego rozwoju zostały opracowane jako strategia UNECE. Zostały one opisane w trzech obszarach z uwzględnieniem czterech filarów (uczyć się, aby wiedzieć, uczyć się, aby działać, uczyć się, aby być i uczyć się, aby żyć wspólnie) wspomnianego raportu Delors'a:

29 W. Furmanek, Kompetencje kluczowe. Przegląd problematyki, [w:] W. Furmanek, M. Ďuris (red.), Kompetencje kluczowe kategoria pedagogiki. Studia porównawcze polsko-słowackie, Wydawnictwo Uniwersytetu Rzeszowskiego, Rzeszów 2007, s. 11-20.

30 H. Hamer, Klucz do efektywności nauczania - poradnik dla nauczycieli, Wydawnictwo VEDA, Warszawa 1994.

31 Należałoby dodać do tej grupy kompetencję informatyczną i znajomość języka nowożytnego, co wynika z najnowszego Rozporządzenia Ministra Edukacji Narodowej z dnia 14 lutego 2017 r. w sprawie podstawy programowej wychowania przedszkolnego oraz podstawy programowej kształcenia ogólnego dla szkoły podstawowej, w tym dla uczniów z niepełnosprawnością intelektualną w stopniu umiarkowanym lub znacznym, kształcenia ogólnego dla branżowej szkoły I stopnia, kształcenia ogólnego dla szkoły specjalnej przysposabiającej do pracy oraz kształcenia ogólnego dla szkoły policealnej (Dz.U. 2017, poz. 356, zał. nr 1 i 2). 
1) Holistyczne ujmowanie świata i łączenie teorii z praktyką - to myślenie integrujące, inkluzyjne, to radzenie sobie z zawiłymi, kompleksowymi zagadnieniami.

2) Przewidywanie zmian: przeszłość, teraźniejszość, przyszłość to czerpanie z przeszłości poprzez angażowanie się w teraźniejszość, rozwiązywanie współczesnych problemów z myślą o przyszłości.

3) Transformacja ludzi, pedagogiki i systemu edukacji - wyjście od ustalenia kim jest nauczyciel, ustalenie istoty nauczania i uczenia się, a następnie przekształcanie systemu edukacji ${ }^{32}$.

Zmiana znaczenia roli nauczyciela jest niezbędna, gdyż systemy edukacyjne tworzą osoby, które w nich pracują. Kluczem do zmiany tych systemów powinny być nauczyciele, potrafiący zmieniać własne działanie.

\section{Zakończenie}

W związku z dynamicznym rozwojem wszystkich sfer współczesnego życia, istnieje pilna potrzeba „ukształtowania” nowego typu nauczyciela. Niezwykle cenne okazują się nowatorskie rozwiązania, otwartość, nowoczesność, kreatywność i innowacyjność w zakresie organizacji procesu wychowania i kształcenia. W dzisiejszym świecie nie można zrezygnować z ciągłego, ustawicznego podnoszenia swoich kwalifikacji, doskonalenia się, poszerzania i aktualizowania wiedzy.

Kompetencje nauczyciela, czyli wiedza, umiejętności i przekonania inspirują jego pracę dydaktyczną, wychowawczą i opiekuńczą. Szczególnego znaczenia nabierają kompetencje nauczycieli związane z edukacją na rzecz zrównoważonego rozwoju. Nauczyciel kompetentny to osoba wykształcona nie tylko ogólnopedagogicznie, ale zdolna do nauczania interdyscyplinarnego, dostrzegająca

32 UNCE, United Nations Economic Commission for Europe Strategy for Education for Sustainable Development. Learning for the future. Competences in Education for Sustainable Development, Genewa 2012, s. 16-17, https://www.unece.org/fileadmin/DAM/ env/esd/ESD_Publications/Competences_Publication.pdf (dostęp: 15.08.2019); por. E. Lewandowska, Edukacja obywatelska - edukacja demokratyczna - edukacja dla zrównoważonego rozwoju, [w:] J. Bałachowicz, A. Korwin-Szymanowska, E. Lewandowska, A. Witkowska-Tomaszewska, Zrozumieć uczenie..., s. 153-157. 
problemy współczesnego świata, co w konsekwencji wpływa na rozwój mistrzostwa pedagogicznego.

\begin{abstract}
The idea or concept of sustainable development can rarely be found in reflections about the modernization of school (kindergarten) and the possibility to change the model and culture of child education in Poland. That idea is combined, most often, with ecological or environmental education, although in recent years its new possibilities have been noticed. The author of the article introduces the concept and the assumptions of sustainable development and its goals. She pays particular attention to the teacher who is responsible for organizing education.
\end{abstract}

\title{
Bibliografia
}

Banach Cz., Nauczyciel, [w:] W. Pomykało (red.), Encyklopedia pedagogiczna, Wydawnictwo Fundacja Innowacja, Warszawa 1993.

Bałachowicz J., Idea zrównoważonego rozwoju w edukacji dziecka, „Prima Educatione" 2017, nr 1.

Bałachowicz J., Korwin-Szymanowska A., Lewandowska E., Witkowska-Tomaszewska A., Zrozumieć uczenie się. Zmienić wczesną edukacje, Wydawnictwo Akademii Pedagogiki Specjalnej, Warszawa 2017.

Bruner J., Kultura edukacji, Wydawnictwo Universitas, Kraków 2006.

Cichy D., Szkoła wobec wyzwań edukacji biologicznej i środowiskowej w XXI wieku, Instytut Badań Edukacyjnych, Warszawa 2001.

Cichy D., Dekada edukacji ekologicznej wzmocnieniem świadomości i działań społeczeństwa na rzecz środowiska, [w:] E. Rydz, A. Kowalak (red.), Świadomość ekologiczna a rozwój regionalny w Europie Środkowo-Wschodniej, Wydawnictwo Naukowe Akademii Pomorskiej, Słupsk 2008.

Degórski M., Postrzeganie rozwiązań zrównoważonego rozwoju w kontekście rosnącej świadomości ekologicznej ludności na przykładzie wybranych gmin $i$ miast obszaru metropolitalnego Warszawy, [w:] E. Rydz, A. Kowalak (red.), Świadomość ekologiczna a rozwój regionalny w Europie Środkowo-Wschodniej, Wydawnictwo Naukowe Akademii Pomorskiej, Słupsk 2008.

Delors J., Edukacja: jest w niej ukryty skarb, Wydawnictwo UNESCO, Warszawa 1998.

Dobrzańska B., Dobrzański G., Kiełczewski D., Ochrona środowiska przyrodniczego, PWN, Warszawa 2010. 
Furmanek W., Kompetencje kluczowe. Przegląd problematyki, [w:] W. Furmanek, M. Ďuris (red.), Kompetencje kluczowe kategoria pedagogiki. Studia porównawcze polsko-słowackie, Wydawnictwo Uniwersytetu Rzeszowskiego, Rzeszów 2007.

Hamer H., Klucz do efektywności nauczania - poradnik dla nauczycieli, Wydawnictwo VEDA, Warszawa 1994.

Kupisiewicz Cz., Dydaktyka ogólna, Wydawnictwo Graf Punkt, Warszawa 2000.

Lewandowska E., Edukacja obywatelska - edukacja demokratyczna edukacja dla zrównoważonego rozwoju, [w:] J. Bałachowicz, A. Korwin-Szymanowska, E. Lewandowska, A. Witkowska-Tomaszewska, Zrozumieć uczenie się. Zmienić wczesną edukację, Wydawnictwo Akademii Pedagogiki Specjalnej, Warszawa 2017.

Paśko I., Uczeń w młodszym wieku szkolnym jako uczestnik edukacji dla zrównoważonego rozwoju, „Pedagogika Przedszkolna i Wczesnoszkolna. Czasopismo Instytutu Pedagogiki Przedszkolnej i Szkolnej Uniwersytetu Pedagogicznego im. Komisji Edukacji Narodowej w Krakowie" 2018, nr 2/2(12/2).

Plit F., Edukacja dla zrównoważonego rozwoju, [w:] E. Rydz, A. Kowalak (red.), Świadomość ekologiczna a rozwój regionalny w Europie Środkowo-Wschodniej, Wydawnictwo Naukowe Akademii Pomorskiej, Słupsk 2008.

Průcha J., Pedeutologia, [w:] B. Śliwerski (red.), Pedagogika. Pedagogika wobec edukacji, polityki oświatowej i badań naukowych, t. 2, GWP, Gdańsk 2006.

Rozporządzenia Ministra Edukacji Narodowej z dnia 14 lutego 2017 r. w sprawie podstawy programowej wychowania przedszkolnego oraz podstawy programowej kształcenia ogólnego dla szkoły podstawowej, w tym dla uczniów z niepełnosprawnością intelektualną w stopniu umiarkowanym lub znacznym, kształcenia ogólnego dla branżowej szkoły I stopnia, kształcenia ogólnego dla szkoły specjalnej przysposabiającej do pracy oraz kształcenia ogólnego dla szkoły policealnej, Dz.U. 2017, poz. 356, zał. nr 1 i 2.

Strategia Edukacji dla Zrównoważonego Rozwoju, Europejska Komisja Gospodarcza ONZ, Ministerstwo Środowiska, Warszawa 2008.

Tuszyńska L., Diagnoza edukacji środowiskowej społeczności lokalnych $w$ wybranych regionach Polski, Wydawnictwa Uniwersytetu Warszawskiego, Warszawa 2008.

Tuszyńska L., Nauki o środowisku przyrodniczym, [w:] A. Korwin-Szymanowska, E. Lewandowska, L. Tuszyńska, Edukacja środowiskowa $w$ kształceniu nauczycieli w perspektywie praktycznej, Wydawnictwo Akademii Pedagogiki Specjalnej, Warszawa 2015. 
Walosik A., Przez edukację do zrównoważonego rozwoju, Wydawnictwo Uniwersytetu Pedagogicznego w Krakowie, Kraków 2013.

Żegnałek K., Dydaktyka ogólna. Wybrane zagadnienia, Wyższa Szkoła Pedagogiczna im. Janusza Korczaka, Warszawa 2005.

\section{Netografia}

Batorczak A., Edukacja dla zrównoważonego rozwoju w Polsce i w Wielkiej Brytanii, rozprawa doktorska, napisana pod kierunkiem dr hab. A. Siemak-Tylikowskiej, prof. UW, https://depotuw.ceon.pl/bitstream/handle/item/457/Praca\%20doktorska.pdf?sequence=1 (dostęp: 05.07.2019).

Pawłowski A., Teoretyczne uwarunkowania rozwoju zrównoważonego, http://towarzystwo.ros.edu.pl/images/roczniki/archive/pp_2009 _071.pdf (dostęp: 30.08.2019).

Polska Komisja ds. UNESCO, UNESCO a Dekada Edukacji dla Zrównoważonego Rozwoju, 2006, http://www.unesco.pl/edukacja/dekada-edukacji-nt-zrownowazonego-rozwoju/unesco-a-zrownowazony -rozwoj/ (dostęp: 30.08.2019).

UNCE, United Nations Economic Commission for Europe Strategy for Education for Sustainable Development. Learning for the future. Competences in Education for Sustainable Development, Genewa 2012, s. 16-17, https://www.unece.org/fileadmin/DAM/env/esd/ESD_Publications/Competences_Publication.pdf (dostęp: 15.08.2019). 